\title{
The Effect of Food Addiction in Children on Obesity: A Systematic Review and Meta-Analysis Study
}

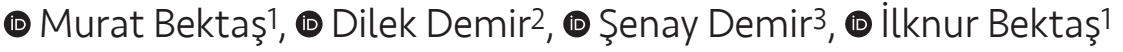 \\ 1Dokuz Eylül University Faculty of Nursing, Department of Pediatric Nursing, İzmir, Turkey \\ ${ }^{2}$ Hakkari University Faculty of Health Sciences, Department of Nursing, Hakkari, Turkey \\ ${ }^{3}$ Selçuk University Faculty of Health Sciences, Physical Therapy and Rehabilitation, Konya, Turkey
}

\begin{abstract}
Aim: This study aimed to analyse the effect of food addiction in children on obesity.

Materials and Methods: A comprehensive literature review was conducted between January 2013 and July 2019 (Google Scholar, Pubmed, Embase/Elsevier, PsycINFO, EBSCOhost, Science Direct, BioMed Central). The word combinations "child", "adolescent", "obesity", "food addiction", "eating behaviour" and "food addiction scale for children" were used in the search process. The selected articles were examined in detail by two independent reviewers, and the methodological quality of the studies to be included in this study were evaluated using the Joanna Briggs Institute Meta-Analysis Statistical Appraisal and Review Tool (JBI-MAStARI Critical Appraisal Tool). General effect size, tests of heterogeneity, publication bias, and sensitivity analyses were performed with the random-effects model. The Comprehensive Meta-Analysis 3 software package was used for data analysis.

Results: As a result of the test of heterogeneity, those studies falling within the food addiction in children sub-dimension were determined to show heterogeneous characteristics $\left(\mathrm{Q}=74,109, \mathrm{I}^{2}=83.80, \mathrm{p}<0.01\right)$. The result of the publication bias test indicated the presence of publication bias. The overall effect size value of all studies, which was found using the random-effects model, was determined to be 0.346 [ $95 \%$ confidence interval (CI)], a value between the $0.152-0.539 \mathrm{Cl}$. According to the results, food addiction was found to have a positive and moderate effect size on obesity when the average effect sizes within a $95 \% \mathrm{CI}$ were considered. Accordingly, food addiction was determined to significantly affect obesity in children $(p<0.05)$.
\end{abstract}

Conclusion: In this study, food addiction in children was determined to affect the prevalence of obesity in children.

Keywords: Child, adolescent, obesity, food addiction, systematic review, meta-analysis

\section{Introduction}

With the increase in the prevalence of childhood obesity across the world in recent years, food addiction has increasingly taken our attention as it is one of the factors affecting obesity (1-3). Food addiction is based on the idea that certain processed, high-calorie, and palatable foods may have addictive potentials and that excessive consumption of these foods can lead to addiction-like behaviours $(4,5)$. How these foods lead to addiction-like eating behaviour is already being debated. It has been suggested that especially processed, high-calorie, and palatable foods rich in sugar, fat, starch, and salt increase the desire to eat by stimulating the reward systems in the 
brain more when compared to other foods and lead to a loss of control over eating behaviour $(6,7)$. With this loss of control over eating behaviour, the desire for addictive foods increases and the desire for healthy food intake decreases, thus increasing the rates of addictive food consumption (6-8). This leads to obesity through the intake of more calories in children $(1,9,10)$.

Despite growing evidence of food addiction among adults, little is known about the role of food addiction in childhood obesity. As developmental stages continue in children, they may be more affected by these addictive foods (6). In one study, the most addictive foods were found to be chocolate, French fries, sugar, ice cream, carbonated drinks, rice, pasta, chips, and white bread (11). In another study of 50 children aged between 8 and 19 years, Merlo et al. (9) determined that $15.2 \%$ of children with overweight or metabolic diseases had food addiction. Food addiction has been found to be largely associated with overeating, uncontrolled eating, emotional eating, over-engagement in food, body sizes, and over-engagement in calorie calculation and control (9). In their study on 150 children between the ages of 5-12 years, Burrows et al. (12) found food addiction at a rate of $22.7 \%$. Food addiction in children has been found to be significantly associated with high body mass index (BMI) scores (12). In a study of 801 adolescents aged between 11 and 18 years, Ahmed and Sayed (13) found food addiction to be $15.7 \%$. Siah et al. (14) found no significant relationship between food addiction and BMI in adolescents. The e-literature indicated that the majority of the studies associating food addiction with obesity in children were studies conducted on children diagnosed with obesity $(11,15,16)$. There are very few comparative studies on how food addiction affects obesity in children who are healthy and who are obese $(15,16)$.

This diversity of these study results, which are already scarce in the literature, makes it difficult to reach a clear conclusion on this subject. These differences in results require re-analysis of the study results with advanced analysis techniques. The best-known statistical method is systematic review and meta-analysis $(17,18)$. However, although systematic reviews and meta-analyses have been conducted throughout the world regarding food addiction involving adults and children, no systematic reviews and meta-analyses have been found to explain the effect of food addiction on obesity in children $(19,20)$. This constituted the main starting point of this study. This study aimed to synthesize the results of studies investigating the effects of food addiction in children on obesity by using systematic review and meta-analysis methods.

\section{Materials and Methods}

\section{Literature Review}

Since no systematic review and meta-analysis studies on this subject were found in the world literature, the starting time of the review was chosen as 2013, when the food addiction scale was first developed. Accordingly, the literature review aimed to access studies between January 2013 and July 2019. In the preparation of the systematic review and meta-analysis, the PRISMA (Preferred Reporting Items for Systematic Reviews and Meta-Analysis Statement) criteria were taken as a base (21). During the data collection phase, studies whose full text could be accessed were included in this study. In the data collection process, seven electronic databases including BioMed Central, Pubmed, Science Direct, PsycINFO, EBSCOHost, Embase/Elsevier and Google Scholar were reviewed.

\section{Review Strategy}

The keywords were generated based on the research question. MeSH (Medical Subjects Headings) was utilized for generating the English keywords, while the content of the Turkey Science Terms web page was used to find the Turkish equivalent of the English keywords. During the online search, keywords "child", "adolescent", "obesity", "food addiction", "eating behaviour", and "food addiction scale for children" and their Turkish equivalents were used. The PICO format was employed to design the research question in the metaanalysis. This format corresponds to the research question population ( $\mathrm{P}$ : population), intervention (I: intervention), comparison groups ( $\mathrm{C}$ : comparison), and results (O: outcomes). The PICO format of our study was as follows: when studies investigating the effect of food addiction in children on obesity were reviewed, the target population of our study was identified as those studies sampling children and adolescents with obesity around the world as the study population (population). The intervention under the PICO acronym was determined as food addiction, while the comparison criterion was determined as healthy children and adolescents. As for outcomes, this criterion referred to children with obesity who had food addiction and healthy children with food addiction.

\section{The Selection of the Studies}

The criteria for including the studies accessed as a result of the review in this study were as follows: a) the study should have a sample range aged between 4 and 21 years; (b) the design of the study should be randomized controlled, quasi-experimental, cross-sectional, case-control, cohort, or similar; (c) variables should include BMI; (d) it should have 
adequate statistical data; and (e) it should employ a valid and reliable food addiction scale for children. On the other hand, the exclusion criteria included duplication, non-inclusion of the BMI variable, and sampling a different population. The selection of the studies for meta-analysis was carried out independently by two researchers. A comparison of the selected studies indicated a 100\% agreement. Studies included in the analysis were arranged under the "PRISMA Flow Diagram" directives, and the flow diagram showing the reduction of 13,646 studies accessed as a result of the review to 13 studies included in the meta-analysis (PRISMA 2009 Flow Diagram) is presented in Figure 1 (21).

\section{Evaluation of the Studies in Terms of Methodological Quality}

The methodological quality of each study was evaluated with the Joanna Briggs Institute Meta-Analysis Statistical Appraisal and Review Tool (JBI-MAStARI critical appraisal tool), which was translated into Turkish by the researcher (22). The Joanna Briggs Institute classifies quantitative research designs into three groups including (1) experimental/quasi-experimental, (2) observational, and (3) descriptive. The checklists developed accordingly are of three types and include a set of evaluation criteria or questions related to research designs. The items on the checklist are generally intended to assess the four types of bias in studies. These are selection bias, performance bias, detection bias, and attrition bias. For each item in the JBIMAStARI checklists, a "Yes" response is assigned 1 point, while responses such as "No", "Not specified", or "Not appropriate" are assigned 0 points. The JBI-MAStARI critical appraisal score ranges from $0-8$. The higher the total score is, the higher the methodological quality of the study is (22). As a result of the evaluation, some studies were determined to be scored between 5 and 8 , and their research quality was evaluated to be medium or high. A summary of the methodological quality appraisal of the studies is presented in Table I.

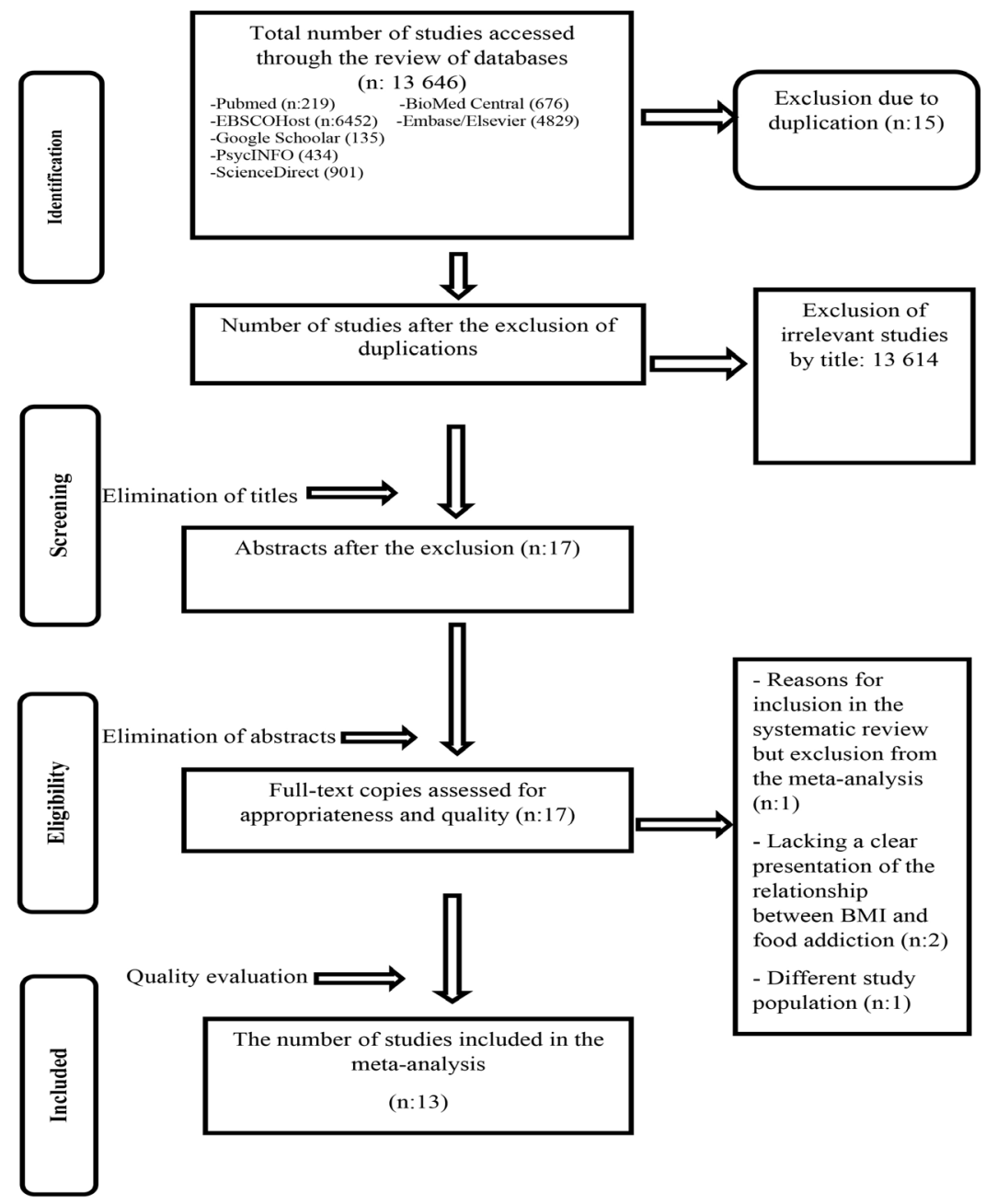

Figure 1. Flow diagram for the selection of the studies 
Table I. A summary of the methodological quality appraisal of the studies investigating the effect of food addiction in children on obesity

\begin{tabular}{|c|c|c|c|c|c|c|c|c|c|}
\hline Studies & 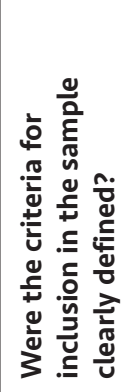 & 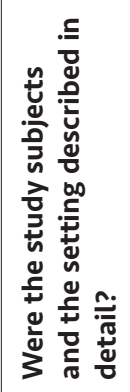 & 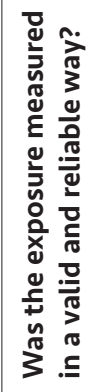 & 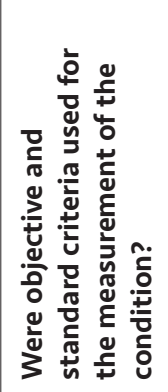 & 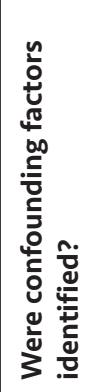 & 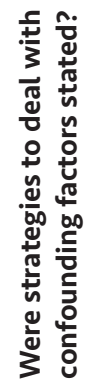 & 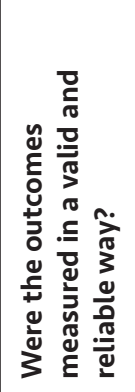 & 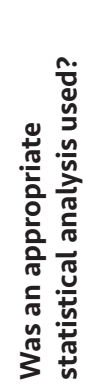 & 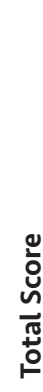 \\
\hline Keser et al. (11) & U & Y & Y & Y & U & U & Y & Y & 5 \\
\hline Burrows et al. (12) & U & Y & Y & Y & $U$ & U & Y & Y & 5 \\
\hline Ahmed and Sayed (13) & Y & Y & Y & Y & U & U & Y & Y & 6 \\
\hline Siah et al. (14) & Y & Y & Y & Y & U & U & Y & Y & 6 \\
\hline Meule et al. (15)* & U & Y & Y & Y & U & U & Y & Y & 5 \\
\hline Tompkins et al. (16)* & Y & Y & Y & Y & U & U & Y & Y & 6 \\
\hline Borisenkov et al. (23) & $N$ & U & Y & Y & Y & Y & Y & $Y$ & 6 \\
\hline Mies et al. (24) & Y & Y & Y & Y & Y & Y & Y & Y & 8 \\
\hline Richmond et al. (25) & Y & Y & $Y$ & Y & Y & Y & Y & Y & 8 \\
\hline Rodrigue et al. (26) & Y & Y & Y & Y & Y & Y & Y & Y & 8 \\
\hline Zhao et al. (27) & N & Y & Y & Y & Y & Y & Y & Y & 7 \\
\hline Naghashpour et al. (28) & Y & Y & Y & Y & Y & Y & Y & $\mathrm{Y}$ & 8 \\
\hline Filgueiras et al. (29) & Y & $Y$ & $\mathrm{Y}$ & Y & Y & Y & Y & Y & 8 \\
\hline
\end{tabular}

\section{Statistical Analysis}

In this study, the group difference method was employed in the analysis of the data. Data were analysed using the Comprehensive Meta-Analysis software (CMA 3.0). "Hedges' g" was used to calculate the effect size $(17,30)$. Cooper (30) classified the effect size as follows: $d \leq 0.20$ is considered as weak, $d<0.80$ as moderate, and $d \geq 0.80$ as big effect size (17). Cohen's effect size classification was used in this study. The fixed or random effects models are used according to heterogeneity analysis (17). The random effect model was used in this study (17). Cochran's Q statistic, $\mathrm{p}$-value, and $\mathrm{I}^{2}$ tests were used to test the heterogeneity of effect sizes. At the significance phase of the $\mathrm{Q}$ test, the limit value for the $p$-value is recommended to be 0.10 . In the evaluation of heterogeneity, if the heterogeneity ratio $\left(\mathrm{I}^{2}\right)$ is less than $25 \%$, then there is no heterogeneity; between $25-50 \%$, it is low; between $51-75 \%$, it is moderate, and above $75 \%$, it is considered to be high (31). Funnel plot graph, Rosenthal and Orwin's fail-safe N, Duval and Tweedie, Egger regression, and Begg and Mazumdar correlations were used for the analysis of publication bias (17). The significance level was accepted as 0.05 .

At the outset, ethics committee approval was obtained from Dokuz Eylül University, Non-Interventional Research Ethics Committee (IRB: 2019/20-14). Since this was a metaanalysis study, no study was conducted on children and their parents. For this reason, it was not necessary to get permission from the children or their parents.

\section{Results}

The systematic review included 17 studies, while the meta-analysis involved 13 studies. Four studies were excluded from the sample because they did not contain the necessary data for the meta-analysis. The sample of the study consisted of children and adolescents aged between 4 and 21 years. The studies included in the systematic review and meta-analysis covered studies conducted between 2013 and 2019. The characteristics of the studies included in the systematic review and meta-analysis are shown in Table II. 
Table II. Systematic summary of studies on the effect of food addiction in children on obesity

\begin{tabular}{|c|c|c|c|c|c|}
\hline $\begin{array}{l}\text { Author-Year } \\
\text { of the study }\end{array}$ & Country & $\begin{array}{l}\text { Research } \\
\text { design }\end{array}$ & $\begin{array}{l}\text { Sample } \\
\text { size }\end{array}$ & Measuring tools & Major findings \\
\hline Keser et al. (11) & Turkey & $\begin{array}{l}\text { Cross- } \\
\text { sectional } \\
\text { study }\end{array}$ & 100 & $\begin{array}{l}\text { Food addiction scale } \\
\text { Socio-demographic/ } \\
\text { anthropometric measurements }\end{array}$ & $\begin{array}{l}71 \% \text { out of } 100 \text { children with overweight } \\
\text { and obesity were found to have food } \\
\text { addiction, which shows that food } \\
\text { addiction plays an important role in } \\
\text { childhood obesity }\end{array}$ \\
\hline $\begin{array}{l}\text { Burrows et al. } \\
\text { (12) }\end{array}$ & $\begin{array}{l}\text { United States } \\
\text { of America }\end{array}$ & $\begin{array}{l}\text { Cross- } \\
\text { sectional } \\
\text { study }\end{array}$ & 150 & $\begin{array}{l}\text { Food addiction scale, } \\
\text { Child feeding questionnaire, } \\
\text { Socio-demographic/ } \\
\text { anthropometric measurements }\end{array}$ & $\begin{array}{l}\text { Food addiction in children was } \\
\text { significantly associated with high } \\
\text { BMI z scores. The mean scores of } \\
\text { food addiction showed a statistically } \\
\text { significant increase from thin to } \\
\text { overweight and obese groups ( } 2.9 \% \text {, } \\
14.7 \%, 32.3 \% \text {, respectively). Mean } \\
\text { addiction scores of normal weighted } \\
\text { subjects were found to be } 50 \%\end{array}$ \\
\hline $\begin{array}{l}\text { Ahmed and } \\
\text { Sayed (13) }\end{array}$ & Egypt & $\begin{array}{l}\text { Cross- } \\
\text { sectional } \\
\text { study }\end{array}$ & 801 & $\begin{array}{l}\text { Food addiction scale, } \\
\text { Socio-demographic/ } \\
\text { anthropometric measurements }\end{array}$ & $\begin{array}{l}\text { The mean scores of food addiction } \\
\text { showed a significant increase from } \\
\text { overweight to the obese group ( } 23.8 \% \\
\text { and } 43.7 \% \text {, respectively). The mean } \\
\text { scores of food addiction were found to } \\
\text { be } 32.5 \%\end{array}$ \\
\hline Siah et al. (14) & Malaysia & $\begin{array}{l}\text { Cross- } \\
\text { sectional } \\
\text { study }\end{array}$ & 333 & $\begin{array}{l}\text { Food addiction scale, } \\
\text { Parental authority questionnaire, } \\
\text { Socio-demographic/ } \\
\text { anthropometric measurements }\end{array}$ & $\begin{array}{l}\text { No significant relationship was found } \\
\text { between food addiction and BMI }\end{array}$ \\
\hline Meule et al. (15) & Germany & $\begin{array}{l}\text { Experimental } \\
\text { study }\end{array}$ & 50 & $\begin{array}{l}\text { Food addiction scale, } \\
\text { Food cravings Questionnaire, } \\
\text { Eating disorder examination } \\
\text {-questionnaire, } \\
\text { Barratt impulsivity scale, } \\
\text { Epidemiological studies, Central } \\
\text { depression scale, } \\
\text { Socio-demographic/ } \\
\text { anthropometric measurements }\end{array}$ & $\begin{array}{l}\text { Nineteen out of } 50 \text { children with } \\
\text { overweight and obesity were reported to } \\
\text { be food addicts }\end{array}$ \\
\hline $\begin{array}{l}\text { Tompkins et al. } \\
\text { (16) }\end{array}$ & $\begin{array}{l}\text { United States } \\
\text { of America }\end{array}$ & $\begin{array}{l}\text { Experimental } \\
\text { study }\end{array}$ & 26 & $\begin{array}{l}\text { Food addiction scale, } \\
\text { Child food power scale, } \\
\text { Pediatric quality of life inventory, } \\
\text { Socio-demographic/ } \\
\text { anthropometric measurements }\end{array}$ & $\begin{array}{l}30.7 \% \text { of adolescents with obesity met } \\
\text { the criteria for food addiction, and } 50 \% \\
\geq 3 \text { reported symptoms of food addiction }\end{array}$ \\
\hline $\begin{array}{l}\text { Borisenkov et } \\
\text { al. (23) }\end{array}$ & Russia & $\begin{array}{l}\text { Cross- } \\
\text { sectional } \\
\text { study }\end{array}$ & 1144 & $\begin{array}{l}\text { Food addiction scale, } \\
\text { Zung self-rating depression scale, } \\
\text { Socio-demographic/ } \\
\text { anthropometric measurements }\end{array}$ & $\begin{array}{l}\text { Food addiction was found to increase in } \\
\text { adolescents with overweight and obesity } \\
\text { ( } p<0.002 \text { ) }\end{array}$ \\
\hline Mies et al. (24) & Netherlands & $\begin{array}{l}\text { Cross- } \\
\text { sectional } \\
\text { study }\end{array}$ & 2653 & $\begin{array}{l}\text { Food addiction scale, } \\
\text { Consumption of sugar with beverages, } \\
\text { Smoking, drugs and alcohol use } \\
\text { behavior, } \\
\text { Socio-demographic/ } \\
\text { anthropometric measurements }\end{array}$ & $\begin{array}{l}2.6 \% \text { of the sample was found to } \\
\text { be food addicts. The mean scores of } \\
\text { food addiction showed a statistically } \\
\text { significant increase from thing group to } \\
\text { overweight/obese group }(1.9 \%, 2.0 \% \text {, } \\
5.9 \% \text {, respectively) }\end{array}$ \\
\hline $\begin{array}{l}\text { Richmond et al. } \\
\text { (25) }\end{array}$ & $\begin{array}{l}\text { United States } \\
\text { of America }\end{array}$ & $\begin{array}{l}\text { Cross- } \\
\text { sectional } \\
\text { study }\end{array}$ & 70 & $\begin{array}{l}\text { Food addiction scale, } \\
\text { Demographic and eating habits } \\
\text { questionnaire, } \\
\text { anthropometric measurements }\end{array}$ & $\begin{array}{l}\text { Among children, food addiction was } \\
\text { more strongly associated with total } \\
\text { calories consumed than BMI }\end{array}$ \\
\hline
\end{tabular}


Table II. continued

\begin{tabular}{|c|c|c|c|c|c|}
\hline $\begin{array}{l}\text { Rodrigue et al. } \\
(26)\end{array}$ & Canada & $\begin{array}{l}\text { Cross- } \\
\text { sectional } \\
\text { study }\end{array}$ & 969 & $\begin{array}{l}\text { Food addiction scale, } \\
\text { Binge eating scale, } \\
\text { Multidimensional anxiety scale for } \\
\text { children, } \\
\text { Beck depression inventory, } \\
\text { UPPS driving behavior scale, } \\
\text { Executive functional behavior } \\
\text { assessment inventory - self-reporting } \\
\text { version, } \\
\text { Socio-demographic/ } \\
\text { anthropometric measurements }\end{array}$ & $\begin{array}{l}\text { Adolescents with higher food addiction } \\
\text { were found to also have a higher BMI }\end{array}$ \\
\hline Zhao et al. (27) & China & $\begin{array}{l}\text { Cross- } \\
\text { sectional } \\
\text { study }\end{array}$ & 593 & $\begin{array}{l}\text { Food addiction scale, } \\
\text { Depression epidemiologic center scale, } \\
\text { Rosenberg self-esteem scale, } \\
\text { UCLA loneliness scale, } \\
\text { Problems and challenges } \\
\text { questionnaire, } \\
\text { Pediatric quality of life inventory, } \\
\text { Socio-demographic/ } \\
\text { anthropometric measurements }\end{array}$ & $\begin{array}{l}\text { Comparison of adolescents with food } \\
\text { addiction to adolescents with no food } \\
\text { addiction indicated that the former had a } \\
\text { higher BMI }(p=0.016)\end{array}$ \\
\hline $\begin{array}{l}\text { Filgueiras et al. } \\
(29)\end{array}$ & Brazil & $\begin{array}{l}\text { Cross- } \\
\text { sectional } \\
\text { study }\end{array}$ & 139 & $\begin{array}{l}\text { Food addiction scale, } \\
\text { Semi-quantitative food frequency } \\
\text { questionnaire, } \\
\text { Socio-demographic/ } \\
\text { anthropometric measurements }\end{array}$ & $\begin{array}{l}95 \% \text { of overweight children showed } \\
\text { at least one of the seven signs of food } \\
\text { addiction. In addition, } 24 \% \text { of children } \\
\text { with overweight were diagnosed with } \\
\text { food addiction. }\end{array}$ \\
\hline $\begin{array}{l}\text { Laurent and } \\
\text { Sibold (32) }\end{array}$ & $\begin{array}{l}\text { United States } \\
\text { of America }\end{array}$ & $\begin{array}{l}\text { Quasi- } \\
\text { experimental, } \\
\text { Cross- } \\
\text { sectional } \\
\text { study }\end{array}$ & 65 & $\begin{array}{l}\text { Food addiction scale, } \\
\text { Child food power scale, } \\
\text { Children's physical activity survey, } \\
\text { Dutch eating behavior Questionnaire } \\
\text { for children, } \\
\text { Depression inventory for children, } \\
\text { Multidimensional anxiety scale for } \\
\text { children, } \\
\text { Socio-demographic/ } \\
\text { anthropometric measurements }\end{array}$ & $\begin{array}{l}38 \% \text { of children were overweight or } \\
\text { obese. Addiction-like eating behavior was } \\
\text { found in } 16 \% \text { of the children and } 4 \% \text { met } \\
\text { the criteria for food addiction }\end{array}$ \\
\hline $\begin{array}{l}\text { Schulte et al. } \\
\text { (33) }\end{array}$ & $\begin{array}{l}\text { United States } \\
\text { of America }\end{array}$ & $\begin{array}{l}\text { Cross- } \\
\text { sectional } \\
\text { study }\end{array}$ & 181 & $\begin{array}{l}\text { Food addiction scale, } \\
\text { Youth eating disorder examination } \\
\text { questionnaire, } \\
\text { Block food frequency questionnaire, } \\
\text { Socio-demographic/ } \\
\text { anthropometric measurements }\end{array}$ & $\begin{array}{l}\text { There were significant relationships } \\
\text { between food addiction scores and } \\
\text { excess weights in adolescents with } \\
\text { obesity. } \\
\text { A significant correlation was found } \\
\text { between food addiction scores and higher } \\
\text { consumption of ultra processed foods } \\
\text { (calorie, fat, saturated fat, trans fat, } \\
\text { carbohydrates, sugar, added sugar) }\end{array}$ \\
\hline $\begin{array}{l}\text { Şanlier et al. } \\
(34)\end{array}$ & Turkey & $\begin{array}{l}\text { Cross- } \\
\text { sectional } \\
\text { study }\end{array}$ & 793 & $\begin{array}{l}\text { Food addiction scale, } \\
\text { Body image scale, } \\
\text { Beck depression inventory, } \\
\text { Socio-demographic/ } \\
\text { anthropometric measurements }\end{array}$ & $\begin{array}{l}\text { A positive relationship was found } \\
\text { between food addiction and BMI. Mean } \\
\text { scores of food addiction showed a } \\
\text { statistically significant increase from } \\
\text { thin group to overweight/obese group } \\
(3.26 \pm 1.21,3.41 \pm 1.33,3.77 \pm 1.54, \mathrm{KW} \\
\text { test }=4,735 ; 0.05)\end{array}$ \\
\hline $\begin{array}{l}\text { Naghashpour et } \\
\text { al. (35) }\end{array}$ & Iran & $\begin{array}{l}\text { Cross- } \\
\text { sectional } \\
\text { study }\end{array}$ & 3908 & $\begin{array}{l}\text { Food addiction scale, } \\
\text { Socio-demographic/ } \\
\text { anthropometric measurements }\end{array}$ & $\begin{array}{l}\text { No significant relationship was found } \\
\text { between food addiction and BMI }\end{array}$ \\
\hline Peters et al. (36) & Germany & $\begin{array}{l}\text { Cross- } \\
\text { sectional } \\
\text { study }\end{array}$ & 228 & $\begin{array}{l}\text { Food addiction scale, } \\
\text { Socio-demographic } \\
\text { Anthropometric measurements/leptin } \\
\text { measurement }\end{array}$ & $\begin{array}{l}\text { There was a weak relationship between } \\
\text { food addiction and leptin in patients with } \\
\text { normal weight ( }(=-0.11, p=0.022) \text {. In } \\
\text { contrast, food addiction was significantly } \\
\text { associated with higher serum leptin } \\
(ß=0.16, p=0.038) \text { in patients with } \\
\text { overweight }\end{array}$ \\
\hline
\end{tabular}


According to the homogeneity test results, the $\mathrm{Q}$ and $\mathrm{I}^{2}$ values for food addiction were calculated to be 74,109 and 83.80 , respectively.

The squares in the graph show the effect size of the related study, and the lines on both sides of the squares show the upper and lower limits of the effect sizes in the 95\% confidence interval (CI). The area of each square shows the weight of the associated study within the overall effect size. The diamond-shaped rhombus at the bottom of the figure shows the overall effect size of the studies (Figure 2).

The effect of food addiction in children on obesity was calculated as a medium effect size according to the random-effects model based on a 95\% significance level. When the effect sizes of the studies were examined, the minimum effect size value was determined to be -0.209 , and the maximum effect size value was 1.086. At the same time, the effect of food addiction on obesity was found to be significant in 7 studies $(p<0.05)$, whereas the effect was not significant in 6 studies $(p>0.05)$. When studies with significant effect size were examined [Ahmed and Sayed (13); Burrows et al., (19); Borisenkov et al., (23); Mies et al., (24); Richmond et al., (25); Rodrigue et al., (26); and Zhao et al., (27)], the effect of food addiction on obesity was found to be positively moderate and strong $(p<0.05$, Figure 2). On the other hand, studies conducted by Keser et al. (11), Meule et al. (15), Tompkins et al. (16), Filgueiras et al. (33), Naghashpour et al. (35), and Siah et al. (14) indicated that the effect size relating to the effect of food addiction on obesity was insignificant and that the eating habits of children did not significantly affect their obesity status ( $p>0.05$, Figure 2). The overall effect size value of all studies was determined to be 0.346 (95\% Cl, SE: standard error $=0.099$ ) in a confidence interval of 0.152 to 0.539 using the random-effects model. According to the random-effects model, when the mean effect sizes in the 95\% confidence interval were examined, food addiction was determined to have a positive and moderate effect on obesity, and food addiction was found to have a significant effect on the obesity status of the child ( $p<0.05$, Figure 2$)$.

For testing the publication bias, the study employed Funnel plot, Egger regression, Duval and Tweedie, Rosenthal and Orwin's fail-safe N, and Begg and Mazumdar's rank correlations. In the study, to have a 0-effect size concerning food addiction in children, 274 studies were needed according to the Rosenthal error protection coefficient, 84 studies according to Orwin's error protection coefficient, and 1 study according to Duval and Tweedie's method. According to Begg and Mazumdar and Egger regression analysis ( $p>0.05)$, there was no publication bias. Also, the existence of publication bias was examined with the help of the Funnel Plot, which is given in Figure 3.

In cases of publication bias in the funnel graph, the effect sizes will appear asymmetrically. In the absence of publication bias, they will show a symmetrical distribution. As is shown in Figure 3, the effect sizes can be said to be in a symmetrical structure. This is one of the cases that show the publication bias is low. As a result of this analysis, it can be said that there may be low publication bias in the study.

\section{Discussion}

The need to understand food addiction, which is thought to be one of the factors affecting the increasing obesity in children, has increased in recent years. Moreover, differences in results of various studies make it difficult to reach a clear conclusion on this subject. Therefore, this meta-analysis study aimed to obtain outcomes with a high level of evidence by taking contradictory situations as a starting point. The meta-analysis conducted in the present study found some evidence showing significant moderate and strong effects of food addiction on obesity.

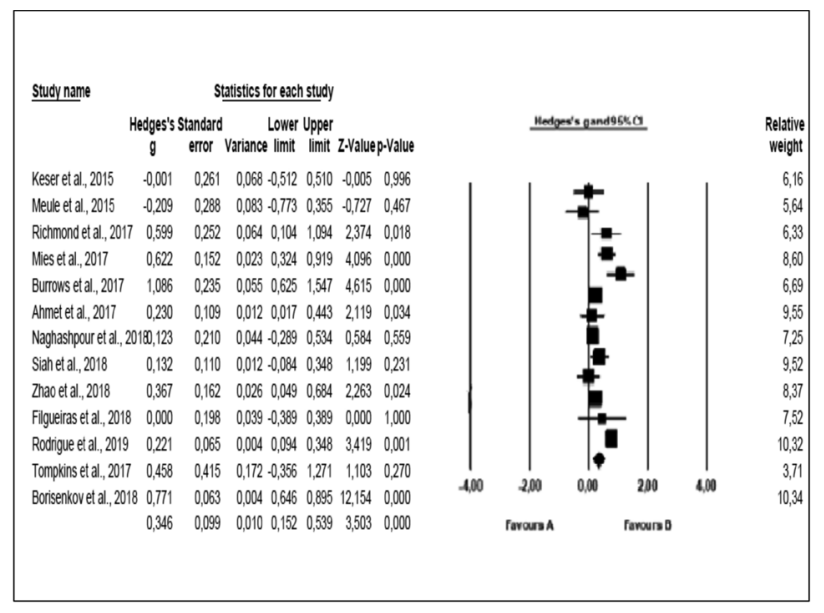

Figure 2. The effect size value of the studies investigating the effect of food addiction in children on obesity

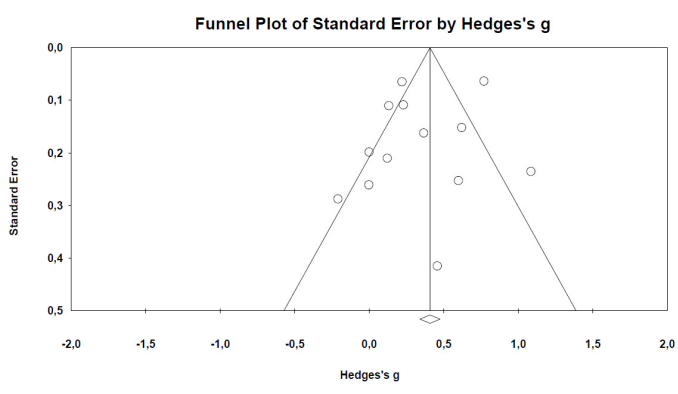

Figure 3. Funnel plot of the effect sizes 
$\mathrm{Q}, \mathrm{P}$ and $\mathrm{I}^{2}$ values were used in the heterogeneity test of those studies included in this meta-analysis. The Q-value was found to be 74,109 , and the $\mathrm{I}^{2}$ value was around 83.80 . In this study, the effect of food addiction in children on obesity was found to be heterogeneous because the $Q$ value was greater than the table $X^{2}$ value and the $I^{2}$ value was above $75 \%$ (31). According to the results of the homogeneity analysis, it was determined that the studies had a heterogeneous structure and that the random effects model should be used. According to sensitivity analyses, when the random effects-model was employed, the results were determined to be similar and the sensitivity was high.

In this study, a total of 17 studies were examined to determine the effect of food addiction in children on obesity. The analyses were conducted with 13 studies that met the inclusion criteria. The sample size of these studies was 10,936. The effect sizes of each study were calculated. In seven studies, food addiction was found to affect obesity, whereas in six studies no significant effect size was found. When the effect sizes of the studies were examined, the minimum effect size value was determined to be -0.209 , and the maximum was 1.086. As a result of the analysis of the studies, food addiction was observed to have a moderate to strong effect size on obesity $(12,13,23-27)$, and the effect size was determined to be statistically significant $(p<0.05$, Figure 2). According to the random-effects model, when the overall effect sizes of all of the studies were examined, food addiction was observed to have a positive and moderate effect on obesity, and food addiction was found to significantly affect the obesity status of the child ( $p<0.05$, Figure 2). Since there were no meta-analysis studies to determine the effect of food addiction in children on obesity, a comparison of the findings of this first study was not applicable.

While some studies in the literature found that food addiction affected obesity in children $(12,13,23,24,26,27,29,32$ $34)$, some studies reported that there was no significant effect $(11,14-16,35,36)$. This meta-analysis study revealed that food addiction had an important role on obesity. In this meta-analysis study, particularly, the sub-dimensions of food addiction were thought to have led to obesity in children. These sub-dimensions included children's desire and cravings for some foods and drinks in spite of feeling full; not being able to prevent themselves from eating certain foods; eating more than needed; feeling guilty while consuming certain foods but after a while finding themselves consuming these same foods; unsuccessful attempts to reduce or stop eating; concealing the fact that they consume unhealthy food; frequently making excuses about why they should consume some foods; and failure in controlling the consumption of certain foods despite knowing that they are harmful to health $(12,13,23-25)$.

For testing the publication bias, the study used Rosenthal and Orwin's error protection coefficient, funnel plot, Duval and Tweedie's method, rank correlation, Egger regression, and Begg and Mazumdar's rank correlations. These analyses calculate the number of studies that may be missing in a meta-analysis $(14,31)$. It is recommended to not use a single method in the determination of the publication bias, on the contrary, a set of methods should be considered. When the Rosenthal error protection coefficient, which is one of the technical methods, was examined, the number of studies required to bring the effect size to zero was found to be large, and this indicated that there was no publication bias in this study. However, when other methods were employed in this study, the majority of the methods revealed that the present study might include publication bias. When examining the results of this meta-analysis, this finding should be taken into consideration.

\section{Conclusion}

This study provides important findings to determine the effect of food addiction in children on obesity. According to the results of this study, when the average effect size of all studies was examined according to the random-effects model, food addiction was found to have a positive and moderate effect size on obesity, and also, it was determined to have a significant effect on the obesity status of the child $(p<0.05)$. In conclusion, food addiction was determined to affect obesity in children. However, the limitation of this study was that the age and gender-related results could not be presented because age and gender-based sub-analyses were not adequate in the studies that were included in the systematic review and meta-analysis. The results of this study are thought to contribute to the knowledge of policymakers and managers so that they can understand the healthy eating behaviour of children and develop strategies for keeping a healthy weight. This study is also expected to provide researchers with a new perspective for future studies. The small number of studies included in this metaanalysis study led to a publication bias; therefore, new studies with a high level of evidence are needed to reveal the effect of food addiction on obesity so that the results can be clarified. In particular, conducting randomized controlled experimental studies and the presentation of effect sizes and power analyses are recommended. In this study, studies employing the same scale were used to maintain objectivity and to prevent bias; for this reason, future meta-analysis 
studies are recommended to include studies with other measurement tools.

\section{Ethics}

Ethics Committee Approval: The study was approved by the Dokuz Eylül University, Non-Interventional Research Ethics Committee (IRB: 2019/20-14).

Informed Consent: This is a meta-analysis study.

Peer-review: Externally peer-reviewed.

\section{Authorship Contributions}

Design: M.B., D.D., Ş.D., I.B., Data Collection or Processing: M.B., D.D., Ş.D., I.B., Analysis or Interpretation: M.B., D.D., Ş.D., İ.B., Literature Search: M.B., D.D., Ş.D., I.B., Writing: M.B., D.D., Ş.D., İ.B.

Conflict of Interest: No conflict of interest was declared by the authors.

Financial Disclosure: The authors declared that this study received no financial support.

\section{References}

1. Burrows T, Meule A. Food addiction. What happens in childhood? Appetite 2015; 89:298-300

2. Ng $M$, Fleming $T$, Robinson $M$, et al. Global, regional, and national prevalence of overweight and obesity in children and adults during 1980-2013: A systematic analysis for the Global Burden of Disease Study. Lancet 2013; 384:766-81.

3. Yardley H, Smith I, Mingione C, Merlo, LI. The role of addictive behaviors in childhood obesity. Curr Addict Rep 2014; 1:96-101.

4. Gearhardt AN, Davis C, Kuschner R, Brownell KD. The addiction potential of hyperpalatable foods. Curr Drug Abuse Rev 2011; 4:140-5.

5. Wilson GT. Eating disorders, obesity and addiction. Eur Eat Disord Rev 2010; 18:341-51.

6. Gearhardt AN, Roberto CA, Seamans MJ, Corbin WR, Brownell, KD. Preliminary validation of the Yale Food Addiction Scale for children. Eat Behav 2013; 14:508-12.

7. Kafes AY, Ülke S, Sayar GH. Food addiction. Curr Addict Res $2018 ; 2: 54-8$

8. Moreno C, Tandon R. Should overeating and obesity be classified as an addictive disorder in DSM-5? Curr Pharm Des 2011; 17:112831.

9. Merlo L), Klingman C, Malasanos TH, Silverstein JH. Exploration of food addiction in pediatric patients. I Addict Med 2009; 3:26-32

10. Pretlow RA. Addiction to highly pleasurable food as a cause of the childhood obesity epidemic: A qualitative internet study. Eat Disord 2011; 19:295-307.

11. Keser A, Yüksel A, Yeşiltepe-Mutlu G, Bayhan A, Özsu E, Hatun Ş. A new insight into food addiction in childhood obesity. Turk Pediatr 2015: 57:219-24.
12. Burrows T, Skinner J, Joyner MA, Palmieri I, Vaughan K, Gearhardt AN. Food addiction in children: Associations with obesity, parental food addiction and feeding practices. Eat Behav 2017; 26:114-20

13. Ahmed AY, Sayed AM. Prevalence of food addiction and its relationship to body mass index. Egypt I Med Hum Genet 2017; $18 \cdot 257-60$

14. Siah PC, Koe ABK, Pang MW, Ng SM, Tan JTA. Parenting styles, food addiction and obesity: A case study of Malaysian Chinese adolescents. Asia Pac J Multidiscip Res 2018; 6:9-14.

15. Meule A, Hermann T, Kübler A. Food addiction in overweight and obese adolescents seeking weight-loss treatment. Eur Eat Disord Rev 2015; 23:193-8.

16. Tompkins CL, Laurent J, Brock DW. Food addiction: a barrier for effective weight management for obese adolescents. Child Obes 2017; 13:462-9.

17. Bakioğlu A, Özcan \$. Meta-analiz. Ankara: Nobel Akademi Yayıncılık; 2016.

18. Jain V, Sharma R, Singh S. Doing meta-analysis in research: a systematic approach. Indian I Dermatol Venereol Leprol 2012; 78:242-50.

19. Burrows T, Kay-Lambkin F, Pursey K, Skinner J, Dayas, C. Food addiction and associations with mental health symptoms: a systematic review with meta analysis. I Hum Nutr Diet 2018; 31:544-72

20. Pursey KM, Stanwell P, Gearhardt, AN, Collins CE, Burrows, TL. The prevalence of food addiction as assessed by the Yale Food Addiction Scale: a systematic review. Nutrients 2014; 6:4552-90.

21. Moher D, Liberati A, Tetzlaff J, Altman DG. The PRISMA Group. Preferred reporting items for systematic reviews and metaanalyses: The PRISMA Statement. PLoS Med 2009; 6:e1000097. doi: 10.1371/journal.pmed.1000097.

22. The Joanna Briggs Institute Critical Appraisal tools for use in JBI Systematic Reviews, 2017. Last Accessed Date: 14.11.2019. Available from: http://joannabriggs.org/research/criticalappraisal-tools.html.

23. Borisenkov MF, Tserne TA, Bakutova LA. Food addiction in Russian adolescents: associations with age, sex, weight, and depression. Eur Eat Disord Rev 2018; 26:671-6.

24. Mies GW, Treur JL, Larsen JK, Halberstadt J, Pasman, JA, Vink $J M$. The prevalence of food addiction in a large sample of adolescents and its association with addictive substances. Appetite 2017; 118:97-105.

25. Richmond RL, Roberto CA, Gearhardt AN. The association of addictive-like eating with food intake in children. Appetite 2017; 117:82-90.

26. Rodrigue C, Gearhardt AN, Begin C. Food Addiction in Adolescents: Exploration of psychological symptoms and executive functioning difficulties in a non-clinical sample. Appetite 2019; 141:104303.

27. Zhao Z, Ma $Y$, Han $Y$, et al. Psychosocial correlates of food addiction and its association with quality of life in a non-clinical adolescent sample. Nutrient 2018; 10:837.

28. Naghashpour $M$, Rouhandeh $R$, Karbalaipour $M$, Miryan $M$. Prevalence of food addiction among Iranian children and adolescents: Associations with sociodemographic and anthropometric indices. Med ) Islam Repub Iran 2018; 32:8. 
29. Filgueiras $A R$, Pires de Almeida VB, Koch Nogueira PC, et al. Exploring the consumption of ultra-processed foods and its association with food addiction in overweight children. Appetite 2018; 135:137-45.

30. Cooper H. Research synthesis and meta-analysis: A step-bystep approach. Thousand Oaks, Kaliforniya: Sage Publications; 2016.

31. Higgins JP, Thompson SG, Deeks II, Altman DG. Measuring inconsistency in meta analyses. BMJ 2003; 327:557-60.

32. Laurent IS, Sibold J. Addictive-like eating, body mass index, and psychological correlates in a community sample of preadolescents. I Pediatr Child Health Care 2016; 30:216-23.

33. Schulte EM, Jacques-Tiura AJ, Gearhardt AN, Naar S. Food addiction prevalence and concurrent validity in African
American adolescents with obesity. Psychol Addict Behav 2018; 32:187-96.

34. Şanlier N, Türközü D, Toka O. Body Image, food addiction, depression, and body mass index in university students. Ecol Food Nutr 2016; 55:491-507.

35. Naghashpour $M$, Rouhandeh $R$, Karbalaipour $M$, Miryan $M$. Prevalence of food addiction among Iranian children and adolescents: Associations with sociodemographic and anthropometric indices. Med I Islam Repub Iran 2018; 32:8.

36. Peters $T$, Antel J, Föcker $M$, et al. The association of serum leptin levels with food addiction is moderated by weight status in adolescent psychiatric inpatients. Eur Eat Disord Rev 2018; 26:618-28 